\title{
New ichnites from the Middle Triassic of the Iberian Ranges (Spain): paleoenvironmental and paleogeographical implications
}

\author{
Georges Gand $^{\mathrm{a}}$, Rau'1 De La Horra ${ }^{\mathrm{b}}$, Belén Galán-Abellán ${ }^{\mathrm{b}}$, José López-Gómez ${ }^{\mathrm{b} *}$, José F. Barrenechea ${ }^{\mathrm{c}}$, Alfredo \\ Arche $^{\mathrm{b}}$ and M. Isabel Benito ${ }^{\mathrm{b}}$ \\ ${ }^{a}$ Biogéosciences UMR 5561, Centre des Sciences de la Terre, Universite' de Bourgogne, 6 Boulevard Gabriel, 21000 Dijon, France; \\ ${ }^{b}$ Facultad de Geología, Instituto de Geología Económica, UCM-CSIC, C/José Antonio Nováis 2, Madrid 28040, Spain; ${ }^{c}$ Departamento \\ de Cristalografía y Mineralogía, Facultad de Geología, UCM, C/José Antonio Nováis 2, Madrid 28040, Spain
}

\begin{abstract}
The Iberian Basin or its present-day expression, the Iberian Ranges, was refilled with red bed sediments of alluvial origin during the late Olenekian-Anisian period represented by the Can izar (Olenekian-Anisian) and Eslida (Anisian) Formations, both commonly known as Buntsandstein facies. In the late part of the Anisian, the Tethys Sea reached the eastern side of the Iberian microplate, represented by the shallow marine facies of the Landete and Can ete Formations, also called Muschelkalk facies. The ichnites studied in this paper belong to the Anisian continental-marine transition in the SE Iberian Ranges.

The Can izar Formation shows the oldest Triassic footprints found in the Iberian Peninsula, consisting in swimming, uncomplete lacertoid three digit Rhynchosauroides traces with possibly resting (cubichnia) and furrowing (pascichnia) Cruziana/Rusophycus due to large triopsids. Specimens from Lacertoi"d and Crocodilor"d groups have been collected in the Eslida Formation. Rhynchosauroides sp. is the most representative ichnospecies of the first group, while in the Crocodiloï group, the presence of Chirotherium barthii Kaup 1835 and Isochirotherium cf coureli (Demathieu 1970) are distinctive. In the Landete Formation specimens are found from Crocodilor"d and Dinosauror"d groups. Brachychirotherium gallicum Willruth 1917, Brachychirotherium sp. and Chirotherium sp. are characteristic of the first one, and 'Coelurosaurichnus' perriauxi and cf Paratrisauropus latus as the most representative of the second group.

Some of the specimens described here present ancestors in the Early Triassic and have been described in the Triassic of North America, Italy and France. Possible paleogeographical connections with faunas of SE France can be inferred.

Based on different sedimentary structures and plant remains, the footprints are related to fluvial systems within huge flood plains, playa and shallow marine environments, with alternating dry and wet periods. The vertical ichnites distribution during the Anisian shows that the fauna modification was weak at a high clade level. In the Triassic of the Iberian microplate, there are no findings of traces prior to the Anisian, and the footprint content for the Middle Triassic is less diversified than in other neighbouring regions. By comparison with other western Pangea areas, there was a later appearance of the forms after the end-Permian mass extinction event in the studied area.
\end{abstract}

Keyword: Rhynchosauroides; Brachychirotherium; Synaptichnium; Paratrisauropus; 'Coelurosaurichnus'; Middle Triassic

\section{Introduction}

Some of the earliest studies on vertebrate footprints in the world were made during the nineteenth century in Spain. The first study of footprints was made by Caldero'n (1897) in the Rillo de Gallo area, Guadalajara Province. During the 1970s, new discoveries were reported by different teams of researchers from several Spanish universities, most of them were reviewed in Demathieu et al. (1978). In the Iberian Ranges, central-eastern Spain, different outcrops between Molina de Arago'n and Sigu"enza (Guadalajara Province) were studied in detail in the siliciclastic red beds (Buntsandstein) and shallow marine dolomites (Muschelkalk) of the Lower-Middle Triassic sections (Figure 1). During the last decades of the past century, new specimens coming from the same sections were described in the SE Iberian Ranges, mostly in Cuenca, Teruel and Castello'n provinces (Lo'pez-Go 'mez 1985). This material, never studied before in detail, and new unpublished discoveries are the backbone of this work. The fossil localities are found in the sections of Camarena, Boniches, Corbala' $n$ and Desierto de Las Palmas (Figure 1). This study improves the Spanish Triassic palichnofauna record and its stratigraphical, paleontological and paleoenvironmental interest is reported here.

\section{Geological setting}

The present-day Iberian Ranges had an early stage represented by the development of the Iberian Basin,

\footnotetext{
*Corresponding author. Email: jlopez@geo.ucm.es
} 


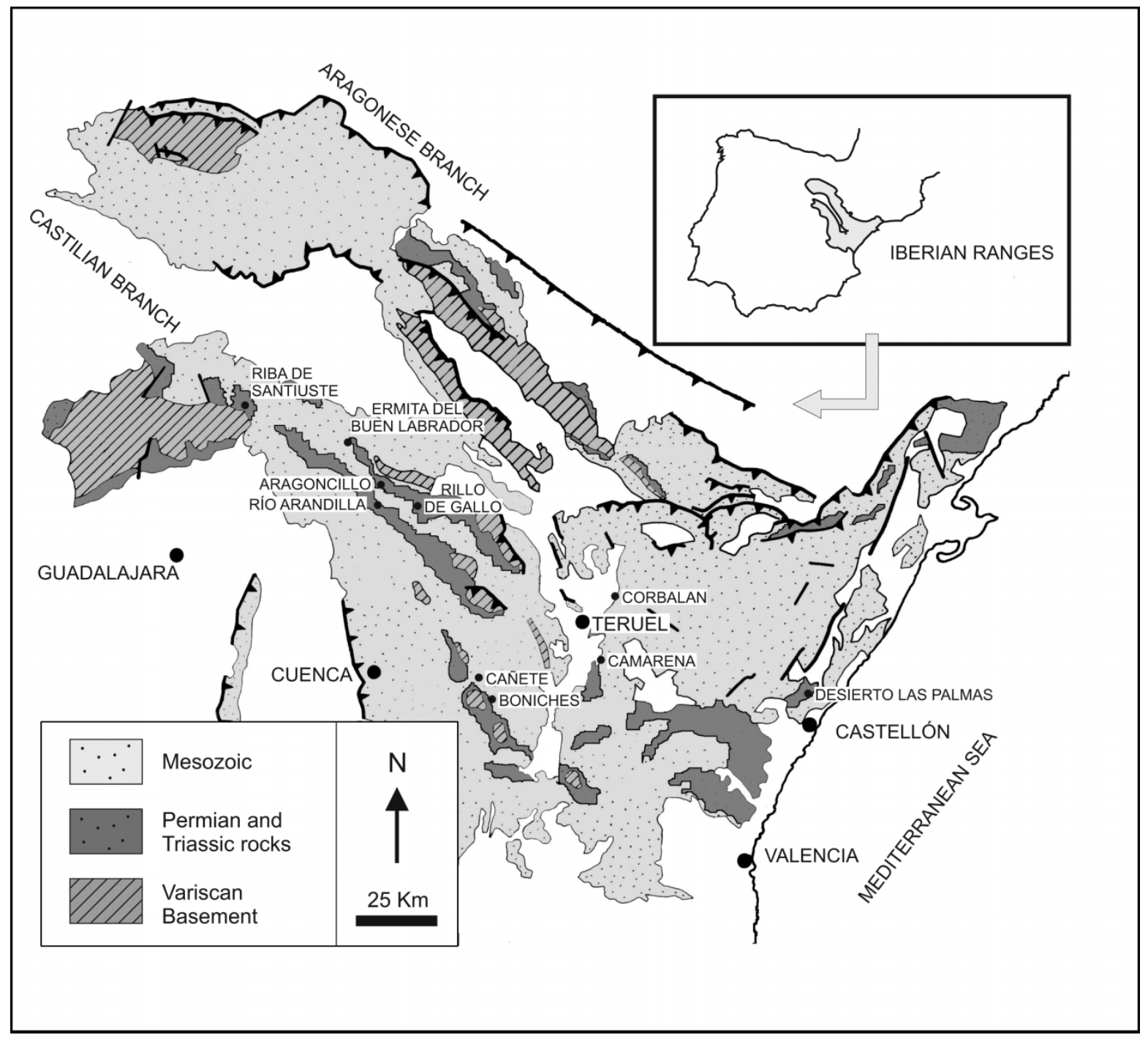

Figure 1. Geographic and geological location of the four studied sections in the SE Iberian Ranges.

an intracratonic basin with its first extensional stages developed during the Middle-Late Permian. This period of extensional character evolved in different phases during the Mesozoic in central-eastern Iberia as part of the breakup of Pangea dynamics (Arche and López-Gómez 1996). The present-day Iberian Ranges are the result of different later Cenozoic Alpine compressional phases that caused tectonic inversion of the previous extensional basins (Sopeña et al. 1988; López-Gómez et al. 2002; De Vicente et al. 2009).

The extensional period (Middle-Late Permian to Late Jurassic) had two main phases, an early one or 'synrift phase', lasting until the Early-Middle Triassic, and a second one, or 'thermal post-rift phase', lasting until Late Jurassic. The latter period of the rifting phase is initially represented by hundreds of metres of red beds (Buntsandstein facies) of alluvial origin, similar to the coeval sedimentary record of most of the WesternCentral Europe domain (Bourquin et al. 2007). Following this period of continental deposition, and also included into the thermal post-rift phase related to a rapid transgressive period, the Tethys Sea covered the eastern part of the Hercynian basement of the Iberia microplate in an onlap-type morphological disposition. During the Middle Triassic, sediments of marine carbonatic platforms, also known in Central and Southern Europe as the Muschelkalk facies, were deposited by different pulses related to two transgressive-regressive cycles (López-Gómez et al. 1998).

The present work is focused on the transition of these two transgressive-regressive phases, that is, the rocks of the upper Buntsandstein facies and the sediments which represent the first marine transgression of the Tethys Sea (lower Muschelkalk facies) in the SE Iberian Ranges. 


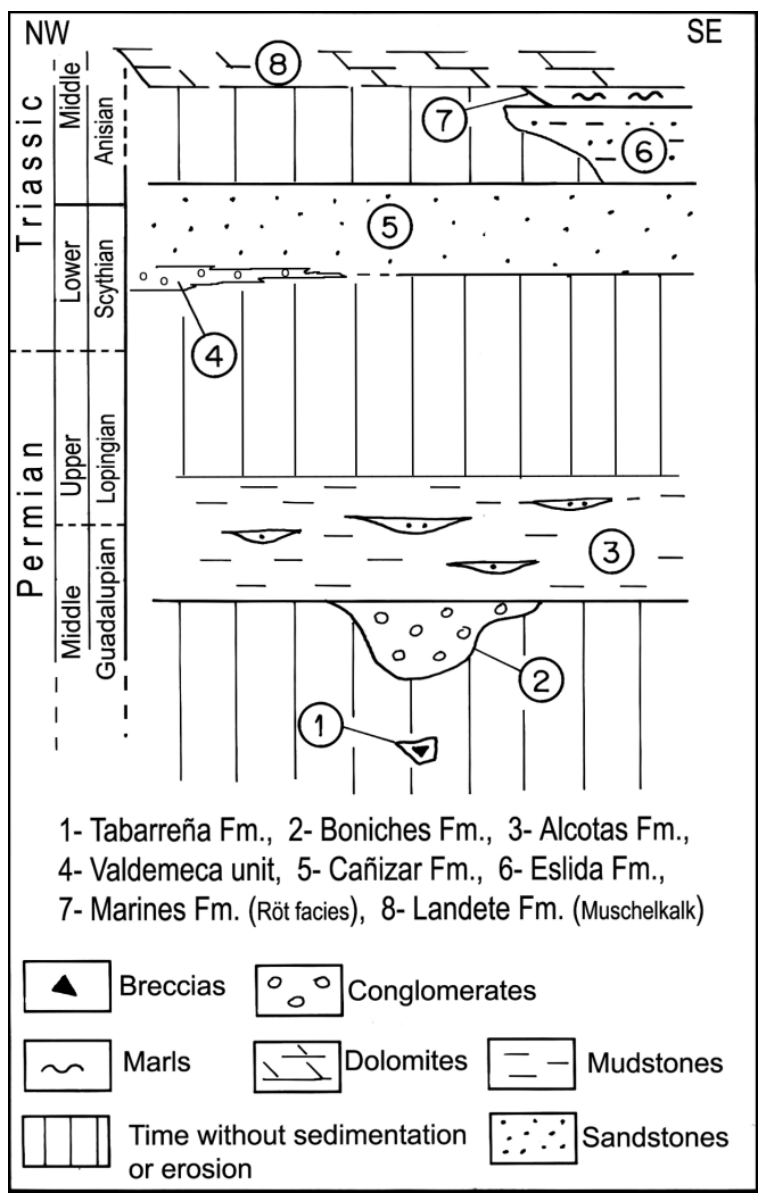

Figure 2. General stratigraphy of the Permian and Triassic lithological units of the studied area in the SE Iberian Ranges.

\section{The sediments}

The Lower and Middle Triassic sediments of the Iberian Ranges were controlled in their deposition by the syntectonic activity of the extensional fault systems creating the sedimentary basins that resulted in a succession of lithological units of characteristic facies (Arche and López-Gómez 2005; Figure 2).

\section{The Buntsandstein facies}

The sediments represented by the red beds are known as the Buntsandstein facies and are subdivided into four lithostratigraphical formations: Valdemeca, Cañizar, Eslida and Marines (Röt), but only the Cañizar and Eslida Formations are within the focus of this work.

The Can izar Formation is up to $170 \mathrm{~m}$ thick and consists of pink to white arkoses with paleocurrents pointing towards the SE. These sediments were deposited in sandy braided fluvial systems of huge lateral extension (López-Gómez and Arche 1993). Its upper part is lower Anisian in age, according to palynomorph assemblages (Doubinger et al. 1990). Sedimentological and palynological data point to a dominant arid environment regime during the time of deposition of this formation (Arche and López-Gómez 2005; Bourquin et al. 2007).

The Eslida Formation is up to $750 \mathrm{~m}$ thick and consists of alternating red to pink sandstones and dark-red mudstones. It is interpreted as braided and punctually mean-dering fluvial systems with intercalated playa lake deposits, conditioned by a rapid tectonic subsidence controlled by NNE-SSW-trending faults systems located to the east of the Iberian microplate (Arche and LópezGómez 1999). The Eslida Formation is dated by palynomorhs as Anisian (Boulouard and Viallard 1982), it is also bounded conformably by well-dated formations of this age. Based on plant remains, sedimentary structures and paleosol characteristics, the deposition of the Eslida Formation is related to a climate regime of alternating humid and semiarid periods (Arche and López-Gómez 2005).

The Marines Formation (Röt facies) is situated at the top of the Buntsandstein red bed sediments and represents the transition from the siliciclastic continental sediments to the shallow marine carbonate rocks of the first marine incursion of the Tethys Sea on the Iberian microplate (López-Gómez et al. 1998). The Marines Formation is up to $65 \mathrm{~m}$ thick and consists of clays, muds and marls with some intercalated thin gypsum levels. The age of this formation is Anisian, according to palynological assemblages (Doubinger et al. 1990). Based on sedimentary characteristics and palynolo-gical data, it is possible to determinate a persistent dry climate in most of the Iberian Ranges and western Tethys areas, during the time of deposition of the Marines Formation. This Formation grades up into the upper unit (lower part of the Muschelkalk facies) in a transitional way, and it is represented by a progressive increase in carbonatic sediments.

The Muschelkalk facies

The progressive development of the Tethys Sea onto the Iberian basin during the Middle Triassic was the result of two main transgression-regression pulses that reached the interior of the Iberian microplate in an onlap disposition (López-Gómez et al. 1998). In general terms, each pulse is represented by a unit of shallow marine carbonatic platform sediments. These two pulses and units are represented by the Muschelkalk facies, while another and younger one is represented by the Imo'n Formation, dated as Raethian (Goy et al. 1976). The lowermost unit is the Landete Formation (López-Gómez et al. 1998) and is the only Muschelkalk facies unit studied in this work, although some footprints, as will be discuss later on, were also found in the upper carbonate platform of the Muschelkalk facies in other sections of the NW Iberian Ranges. The Landete Formation is of Anisian age based on the study of foraminifer assemblages by Márquez et al. (1994). 


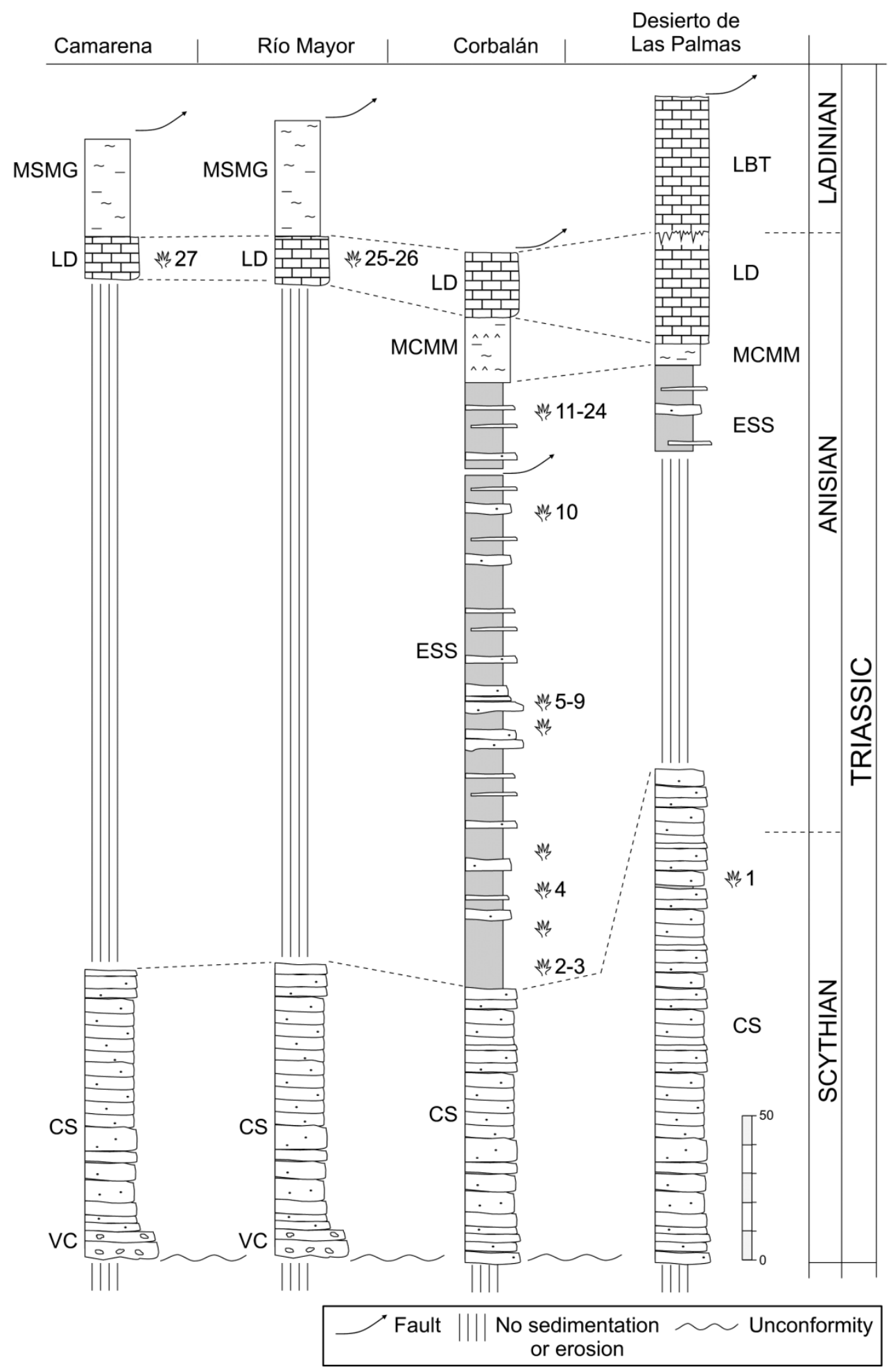

Figure 3. The four studied Triassic sections in the SE Iberian Ranges Rio Mayor Section is located $1.5 \mathrm{~km}$ west of Can ete in figure 1. Numbers correspond to the studied samples. These are: 1: Cañizar R2D2; 2: Ant. 100; 3: Ant. 102; 4: Ant. 104; 5: Ant. 105; 6: Ant. 30; 7: Ant. 30A; 8: Ant. 30-6; 9: Ant.108; 10: Ant. 37; 11: ECor. 214; 12: ECor. 214-3562; 13: ECor. 214-3569; 14: ECor. 215; 15: ECor. 216- 3679; 16: ECor. 217; 17: ECor. 217-3595; 18: ECor. 217-3586; 19: ECor. 217-3581; 20: ECor. 217-3583; 21: ECor. 218; 22: ECor. 218-b; 23: ECor. 218-3599; 24: ECor. 218-ab; 25: Boniches X; 26: Boniches Y; 27: Camarena X. Code for the Units: MSMG, Mas Sandstones Marls and Gypsum; LD, Landete Dolomites; CS, Cañizar Sandstones; VC, Valdemeca Conglomerates; MCMM, Marines Clays, Marls and Mudstones; ESS, Eslida Sandstones and Siltstones; LBT, Levantine-Balear Triassic. 


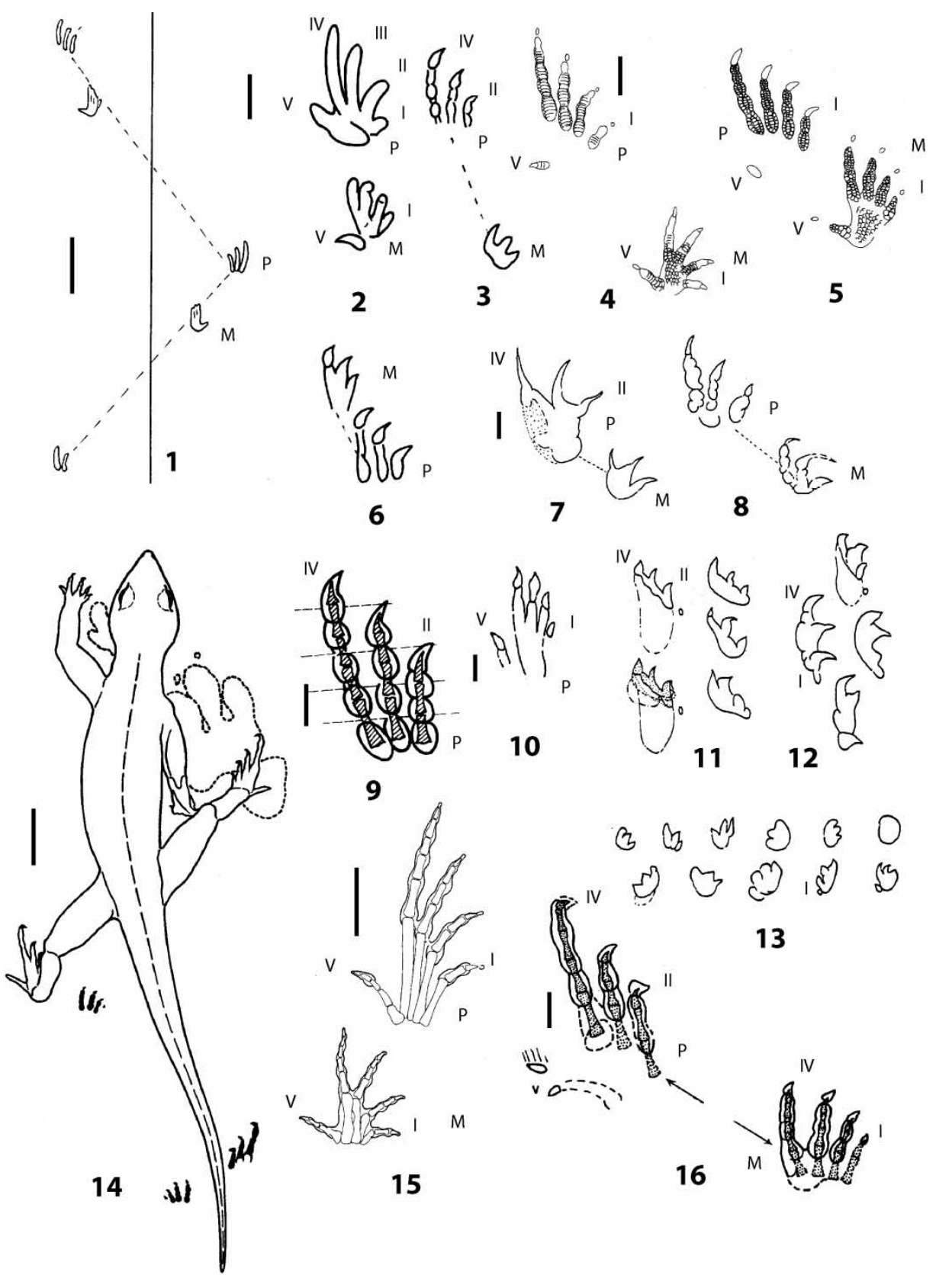

Figure 4. 1, 2-8, 10-13: Variability in Rhynchosauroides, P: pes, M: manus, I, II, III, IV, V: digit numbers, 2-3, 6 in Demathieu 1970; 4-5, respectively, R. peabody and R. tirolicus in Avanzini and Renesto 2002; 7-8: R. triangulus in Gand 1978a; 10-12: pes, 13: manus of R. cf petri in Gand 1977; bone structure inferred from R. petri Demathieu 1966 for 9, R. hyperbates, Baird 1957 for 16; 15: Rhynchosauroides inferred from the Macrocnemus bassanii skeleton in Avanzini and Renesto 2002; 1: Rhynchosauroides petri trackway in Demathieu 1970; 14: trackmaker of R. hyperbates in Baird 1957; scale bars: $5 \mathrm{~cm}$ for 1, 14, and $1 \mathrm{~cm}$ for the others; scale bar of 2 valuable for 3, 6; idem for $4-5,7$ for 8 and 10 for 11-13.

The studied sections

Figure 3 shows the four studied sections. All the Triassic rocks of these sections lie unconformably on the Permian sediments at their base.

From the lower Anisian to the upper Ladinian, a differential subsidence between the NW and the SE areas led to thicker sedimentary records in the latter area. Thus, while the Eslida and Marines Formations (upper Buntsand-stein facies) were deposited in the Corbalán and Desierto de Las Palmas area, a clear sedimentary interruption was formed between the Cannizar and Landete Formations in the Camarena and Boniches areas (Arche and López-Gómez 


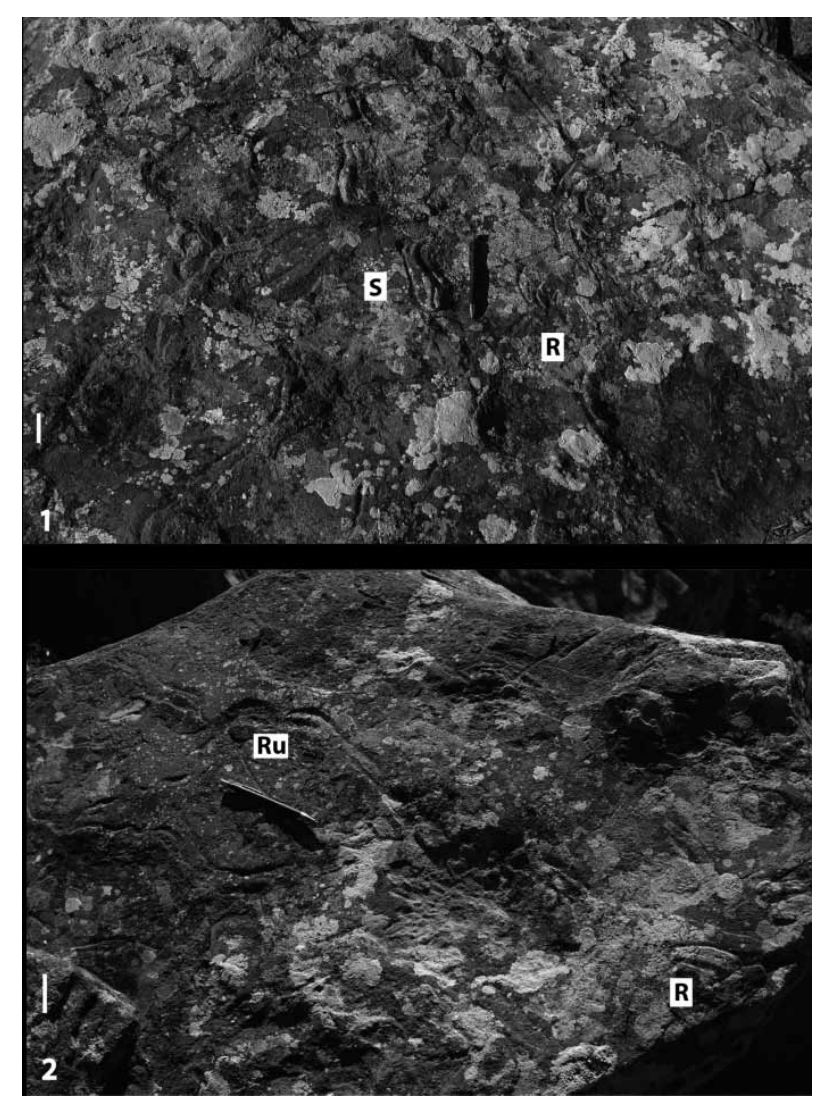

Figure 5. Two different views of the sample Cañizar R2D2, obtained from the upper part of the Cañizar Formation. 1: S, Uncompleted swimming lacertoid trackways with three parallel digit scratches; R, Rhynchosauroides; scale bar $1 / 45 \mathrm{~cm}$; 2: cf Rhynchosauroides $(1 / 4 \mathrm{R})$ on the right border side; RU, double parallel sinuous traces forming kind of furrows. It could be a cubichinia (resting trace)/pascichinia (furrowing) succession; May be Cruziana/Rusophycus of large triopsids. Scale bar $1 / 4$ $5 \mathrm{~cm}$.

2005). Differential subsidence, caused by regional tectonics, together with the transgressive-regressive dynamics of the Tethys sea into the Iberian microplate, led to the deposition of a thicker sedimentary sequence of dolomites (Muschelk-alk facies) in the SE area in comparison with the NW area (Arche and López-Gómez 1996). Only during the Late Triassic times (middle Carnian), a period of relative tectonic quiescence allowed a similar carbonatic deposition in the whole eastern Iberian microplate.

Footprints descriptions and results

General location of the samples

The new ichnites presented in this work were found in four stratigraphical sections (Figure 3). A total of 27 ichnite samples, numbered from the oldest one to the youngest one, are described here. The samples were obtained from the Cañizar, Eslida and Landete Formations, all of them in high-quality outcrops with good vertical and lateral continuity in all the studied area. From base to top, the general location of the footprints in the sections is as follows (Figure 3):

In the Desierto de Las Palmas section, different lacertoid trackways (sample 1) were found at the upper third part of the Cañizar Formation. Based on its location, this is the oldest sample in this study and probably has a lowermost early Anisian age.

In the Corbala'n section, eight levels bearing several footprints were discovered from near the base to the top of the Eslida Formation (samples 2 to 24). They appear on small decimetric micaceous mudstone and fine-grained sandstone sequences whose limited lateral extent does not allow to observe trackways. Therefore, footprints are only manus and pes traces, most of them reported as Rhynchosauroides and, two of them, attributed to Chirotherium barthii and Isochirotherium cf. coureli.

In the Boniches section, a fragmentary dinosauroid trace (sample 25) was collected by one of the co-authors (J L-G) at the base of the Muschelkalk, in the Landete Formation. This sample was lost and it is preserved only by one photo from López-Gómez (1985), which is used in this work. In similar levels of the same outcrop, co-author (GG) has recently discovered several chirotherioid and dinosauroid traces on the surface of a large loose block (sample 26), easily located in its original place in the outcrop. Also in the lower part of the Landete Formation, some $10 \mathrm{~km}$ north of Boniches, near to Camarena, a large slab bearing Brachychirotherium gallicum footprints (sample 27) was found by another co-author (AA) and later on referred in López-Gómez (1985), but was never studied in detail. This sample is today stored and exhibited at the Cuenca Science Museum.

Lacertoid and Rhynchocephaloid Groups Nopsca, 1923; (Cañizar and Eslida Formations)

Ichnogenus Rhynchosauroides Maidwell, 1911

This ichnogenus gathers a great number of ichnospecies listed in Haubold (1971), Avanzini et al. (2001) and Avanzini and Renesto (2002) in Italy, and Gand et al. (2007) in France. In Spain, four ichnospecies were described in the Triassic of the Iberian Ranges by Demathieu et al. (1978), in the Basque Country (Demathieu and Saiz de Omen aca 1976) and in the Cantabrian Cordillera (Demathieu and Saiz de Ome naca 1979, 1990).

All of them were made by quadrupedal animals whose autopod traces are digitigrade to semi-plantigrade, finely clawed and pentadactyl, when they are complete (Figure 4, 2 ). The thin and flexuous digits are clearly spread out going from I to IV in the pes and only from I to III in the manus, because the IV length is similar to that of the III. 


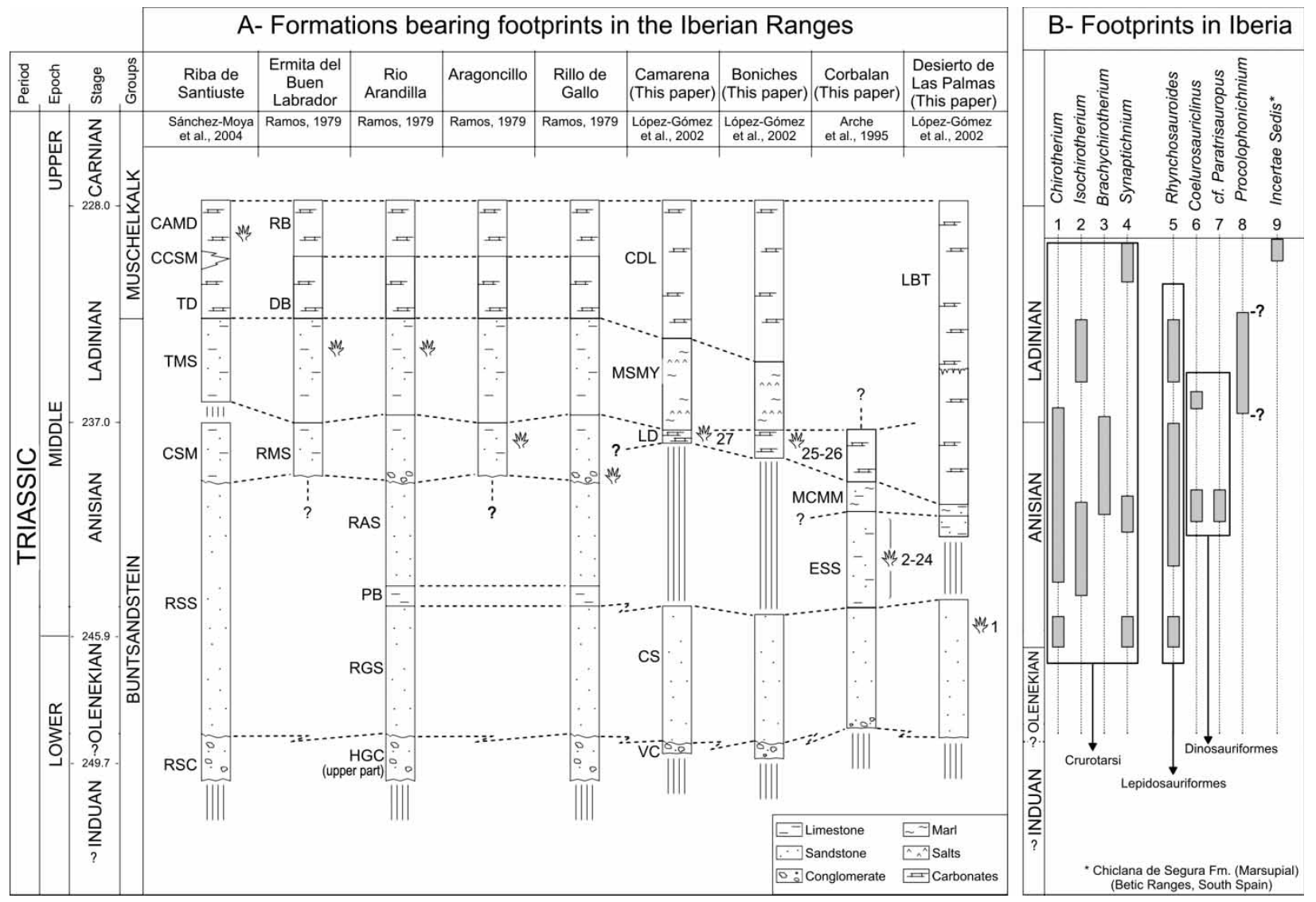

Figure 6. (A) Formations bearing Triassic footprints in the Iberian Ranges. Ages and correlations are indicated. Stratigraphical units are: CCSM, Cuesta del Castillo Sandstones and Mudstones; CAMD, Cuevas de Ayllo'n Mudstones and Sandstones; TD, Tramacastilla Dolomites; TMS, Torete Mudstones and Sandstones; CSM, Cercadillo Sandstones and Mudstones; RSS, Riba de Santiuste Sandstones; RSC, Riba de Santiuste Conglomerates; RB, Royuela Beds; DB, Dolomitic Beds; RMS, Rillo Mudstones and Sandstones; HGC, Hoz del Gallo Conglomerates; RGS, Rillo de Gallo Sandstones; PB, Prado Beds; RAS, Río Arandilla Sandstones; CDL, Cañete Dolomites and Limestones; MSMG, Mas Sandstones Marls and Gypsum; LD, Landete Dolomites; CS, Can izar Sandstones; VC, Valdemeca Conglomerates; MCMM, Marines Clays, Marls and Mudstones; ESS, Eslida Sandstones and Siltstones; LBT, Levantine, Balear Triassic.(B) Footprints vertical range in the Cantabrian Mountains, Catalan Coastal Ranges and Iberian Ranges. Locations in the Cantabrian Mountains: R. santanderensis from Puentenansa section, 40m below the Upper Triassic limit, Demathieu and Sainz de Omeñaca 1976; R. extraneus and R. simulans, level 43 of Puentenansa section, Demathieu and Sainz de Omen aca 1979; R. sp from Cueto Cuco'n section in Pen a Sagra area, mentioned by Demathieu and Omeñaca 1979. Locations in the Catalan Coastal Ranges: R. sp and R. cf. beasleyei from the Triassic Catalonia serie (Calzada 1987; Gaete et al. 1996). Locations in the Iberian Ranges: R. Virgilae, Rillo de Gallo section, Demathieu et al. 1978, Sainz de Omeaca 1976; Chirotherium sp, Aragoncillo section, in Demathieu et al. 1978; Chirotherium sp, Cañete-Boniches section, Lapparent 1966; Synaptichnium sp, Rillo de Gallo (Buntsandstein) and Riba de Santiuste (Muschelkalk) sections; Chirotherium sp, Rillo de Gallo section, Caldero'n 1897 1/4 C. gallicum for Leonardi 1959; Isochirotherium sp., Ermita del Buen Labrador section, Demathieu 1978; Brachychirotherium gallicum, Camarena section; 'Coelurosaurichnus' sp., Rillo de Gallo section, Demathieu 1978; 'Coelurosaurichnus' c f perriauxi, Boniches section; cf Paratrisauropus latus, Boniches section; Chirotherium barthii, Corbala'n section (Eslida Fm).

In the pes, the $\mathrm{V}$ digit print is shifted behind, angled laterally outwards the I-IV digits, and it is often reduced to its claw mark as is the case for the I toe (Figure 4, 4-5, $10,16)$. In several cases, the impression of scales are preserved as in R. peabody (Faber 1958; Demathieu and Oosterink 1983; Diedrich 2000) and R. tirolicus (Abel 1926; Avanzini and Renesto 2002; Figure 4, 4-5).

In the studied trackways, the manus position is variable compared to the pes (Figure 4,1-6), but it is generally located at the back of the pes (Figure 4, 1, 3-5, 7-8, 16) clearly indicating rear limbs longer than forelimbs (Figure 4, 14).

Based on comparisons between Triassic skeletons and our own interpreted reconstructions obtained from the studied footprints, as well as from the animal morphology suggested by the trackway measurements, these Rhynchosauroides are related to different trackmakers. They all are lacertoid reptiles which could have been rhynchosaurians by comparison with different trackways from North America (Peabody 1948; Figure 4, 14), possibly 

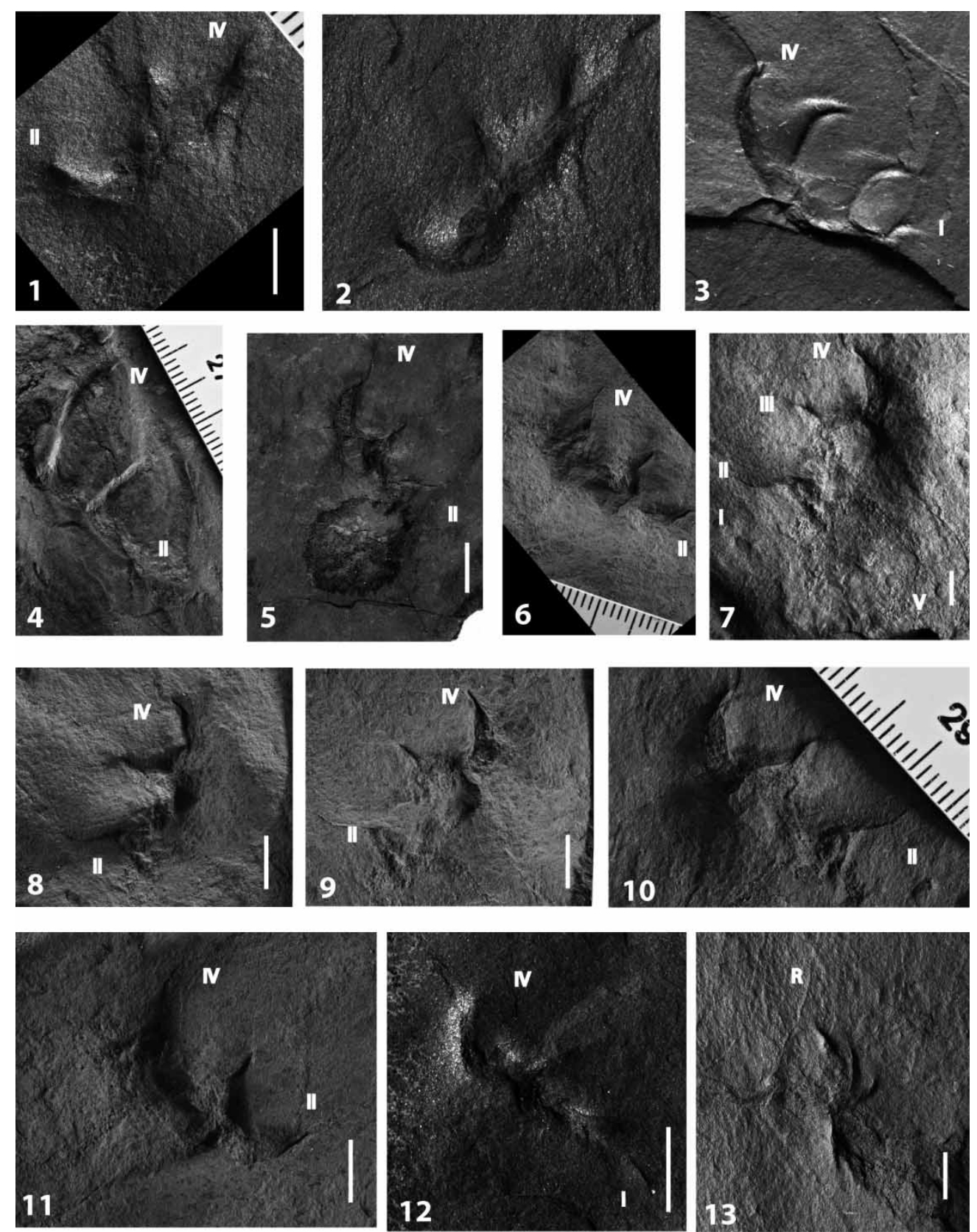

Plate 1. Eslida Formation, Rhynchosauroides sp. 1-2: ECor 214-3562 and ECor 214- 3569 1/4 possible manus footprints reduced to distal II-IV digits; 3-12: tridactyl pes also reduced to distal II-IV digits except 7 showing I and V digits more from slight sharped claw tip, 3: ECor. 215; 4: ECor. 216-3679; 5: ECor. 218- ab; 6: ECor. 217-3583; 7: ECor. 217; 8: ECor. 217-3581; 9: ECor. 217-3586; 10: ECor. 218-3599; 11: ECor. 217-3595; 12: ECor. 214; 13: ECor. 218b (root traces surrounding Rhynchosauroides). Ruler elementary division: $1 \mathrm{~mm}$ (scale of picture 1 valuable for photos 3, 10,11, 12 and 13).

rhynchosaurians or prolacertiforms such as Macrocnemus for R. petri Demathieu 1966 (Demathieu 1970), rhyncho-saurians sphenodontidae related to R. hyperbates Baird 1957 (Silvestri and Olsen 1988), and prolacertiforms such as Macrocnemus bassanii related to R. tirolicus Abel 1926 (Avanzini and Renesto 2002).
Rhynchosauroides sp. from the Corbala'n section (Eslida Formation)

\section{Description}

These footprints often appear grouped and oriented in random directions on the slabs where they do not exceed $40 \mathrm{~mm}$ length. They are generally incomplete, represented 
by the II-IV distal ends digits, finely clawed and bent internal sidewards. Plate $1(1-13)$ and Plate $2(6,8)$ show round and thin marks interpreted as the I and $\mathrm{V}$ claw ends of pes traces. Plate $2(5,9)$ shows manus prints recognizable from the III and IV digits, similar in dimensions.

The incomplete Rhynchosauroides morphologies of the Eslida Formation are similar to many footprints that were described in the French Triassic (Gre`s Infe 'rieurs Formation) of the eastern border of the Massif Central by Demathieu (1970) and Gand (1978a). Some of them were collected in Culles-les-Roches (Burgundy site), close to R. petri Demathieu 1966, and represented in Figure 4 (11-12). In both cases, for the French and Spanish footprints, their subdigitigrade morphology is due to the
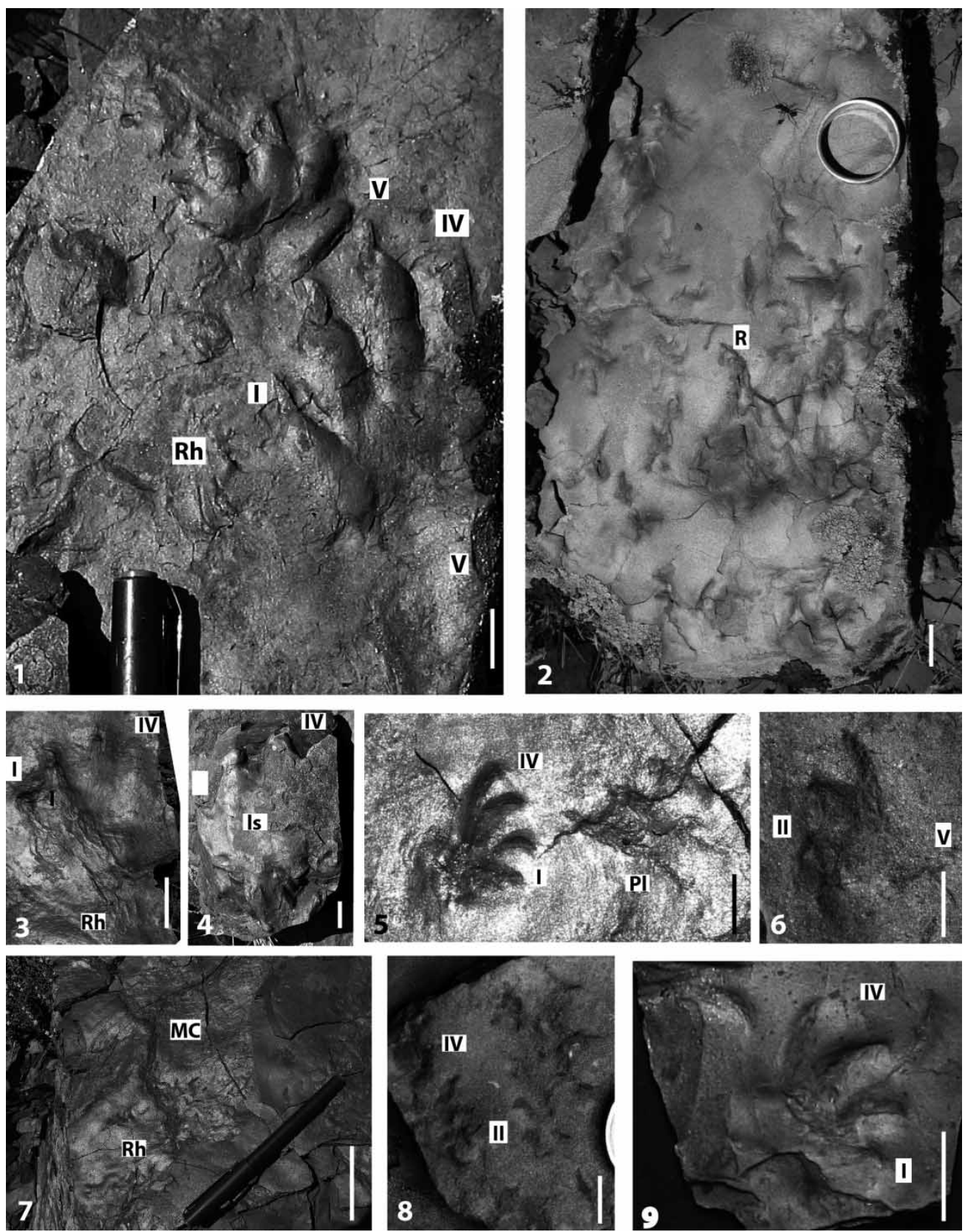

Plate 2. Eslida Formation, Chirotherium, Isochirotherium and Rhynchosauroides footprints. 1: Manus-pes Chirotherium barthii with Rh 1/4 Rhynchosauroides sample Ant. 100; 2: Numerous Rhynchosauroides (R), sample Ant 30A; 3: Uncomplete I-IV digit pes, sample Ant. 104, Isochirotherium cf coureli; 4: Uncomplete I-IV digit pes chirotherioid, (the ichnofossiliferous slab is laid on the C. barthii, sample Ant. 100); 5-9: Slabs bearing Rhynchosauroides; 5: I-IV digit manus with plants (P1), sample Ant. 30; 6: Probable pes, sample Ant. 37; 7: Footprints Rh with mud-cracks, sample Ant. 105; 8: Uncomplete pes traces, sample Ant. 30-6; 9: I-IV digit manus, sample Ant. 108-1181. Scale-bars: $1 \mathrm{~cm}$, except for 3 and $7: 5 \mathrm{~cm}$. 
fast speed of the trackmakers moving on wet substrates, where there are also in situ plant remains (Pl) and rootmarks (R) (Plate 1, 13 and Plate 2, 5).

Swimming uncomplete Rhynchosauroides trackways with three digit scratches and possible resting (cubichnia) and furrowing (pascichnia) traces from sample 1 are shown in Figure 5 (1 and 2, respectively).

Comparison with previously described Spanish ichnospecies (1976-1987)

Rhynchosauroides footprints were described before in other localities of Spain. Apart from the ones from the Eslida Formation, R. santanderensis Demathieu and Saiz de Omen aca (1976) was defined from eight traces which were collected $40 \mathrm{~m}$ below the Triassic upper boundary in Puentenansa, Cantabrian Cordillera. Some of them are swimming prints (Demathieu and Saiz de Omen aca 1976; Figures 2 and 3). The rest are represented by very wide IIIV straight digits (Figure 2(C) of the latter authors) and are similar to some footprints of the Eslida Formation described in this paper (Plate 1,1-2).

In Triassic sections of the Cantabrian Cordillera, Demathieu and Saiz de Omeñaca (1979) defined R. extraneus and R. simulans from fragmentary material coming from the 'tramo 43'. In the same area, Demathieu and Saiz de Omeñaca (1990) quoted one pentadactyl manus - pes couple Rhynchosauroides sp. from the surroundings of Cueto Cuco'n in the Pen a Sagra area.

Rhynchosauroides virgiliae, Demathieu and Saiz de Omen aca (1976) and Demathieu et al. (1978), were defined from numerous samples from the Middle Triassic of the Iberian Ranges (upper Buntsandstein facies, Rillo de Gallo, Guadalajara) and the Eastern border of Massif Central (France). These footprints show slender digits, generally incomplete, in the pes marks.

Calzada (1987) presented some Rhynchosauroides sp. and R. cf. beasleyei tracks (determined by Demathieu) which were collected from the base of the Triassic series of Catalan Coastal Ranges without any precise location.

As many Triassic ichnospecies of Rhynchosauroides, these ones described here have small differences among them. Probably, these differences are not very significant due to the substrate nature and because they were originated by the variable speed gait of the animals. Therefore, we prefer to present the incomplete Rhynchosauroides of the Eslida Formation in open nomenclature as we cannot compare them with other numerous taxa defined from other complete footprints.

Crocodiloid Group Nopsca, 1923; Crurotarsi Sereno and Arcucci, 1990

Ichnogenus Chirotherium Kaup, 1835.

Ichnospecies Chirotherium barthii Kaup 1835; Corbala 'n section, Eslida Formation.
In contrast to many ichnotaxa, Chirotherium barthii remains stable since its creation in the nineteenth century. It is clearly represented by a pentadactyl and heteropod manus-pes couple coming from the base of the Eslida Formation (Plate 2, 1).

The pes trace is approximately 2.6 times longer than that of the hand. It is longer (L) than broad (W):(L £ W 1/4 $84 £ 38 \mathrm{~mm}$ ), with strongly clawed digits having rather well-marked pads. The tridactyl II-IV unit is clearly larger than the length of toe $\mathrm{I}$. The $\mathrm{V}$ is lost and the long and only broad mark of the metatarsals pad is showhe manus trace is a little longer than broad ( $\mathrm{L} £$ W $1 / 433 £ 28 \mathrm{~mm}$ ). The digits are clawed except for the $\mathrm{V}$ which is not very well printed. The $\mathrm{V}$ metacarpal trace is long, located at the back of the I-IV digital part, wider than longer (W £ L 1/4 $28 £ 23 \mathrm{~mm}$ ).

Ichnogenus Isochirotherium Haubold, 1971.

Isochirotherium cf coureli (Demathieu 1970) Haubold 1971; Corbala'n section, Eslida Formation.

A pes trace from sample Ant-104 (Plate 2, 3), located some $24 \mathrm{~m}$ above the bed bearing $\mathrm{C}$. barthii, shows the IIV digital part, whose the I-III digits are ended by balled claws in shape, typical of I. coureli defined in the Middle Triassic of France by Demathieu (1970). From this character but also from the III-II length ratio $1 / 41.03$, this footprint appears like Isochirotherium close to coureli. In this French ichnospecies, the III/II confidence interval is included between 0.96 and 1.09 at the $95 \%$ statistical limit.

*Ichnogenus Brachychirotherium Beurlen, 1950

Brachychirotherium gallicum Willruth 1917, Camar-ena section, Landete Formation.

This ichnotaxa is represented by a $29 \mathrm{~cm}$ long pace which consists of two manus traces $(\mathrm{M})$ connected with a pes (P) (Plate 3, 9). The pentadactyl pes is plantigrade. It is longer than broad with $\mathrm{L} £ \mathrm{~W} 1 / 4110 £ 76 \mathrm{~mm}$. The lengths differences of I-IV toes are as follows: I, II 1/4 IV , III. These digits are slightly clawed, especially the fourth. The complete plantigrady character as well as the weakness of the obliqueness defined by the III digit and the articular digito-metatarsian I-IV axis angle of 608, differentiates it from the Chirotherium pes, which shows a value near of 908. The $\mathrm{V}$ digit is short and extends anterolaterally the long tarso-metapodial pad.

The digitigrade manus is as long as broad with $\mathrm{L} £ \mathrm{~W} 1 / 454 \mathrm{~mm}$. The manus length is twice shorter than that in the pes. Based on some formulae described in Soergel (1925) and Baird (1957), the trunk length is assessed at $50 \mathrm{~cm}$. So, possibly the trackmaker was a quadruped reptile of about $2 \mathrm{~m}$ long.

Chirotherioid traces.

In the same bed bearing $\mathrm{C}$. barthii (cf supra), it was found a chirotherioid trace which is reduced to the I-IV 

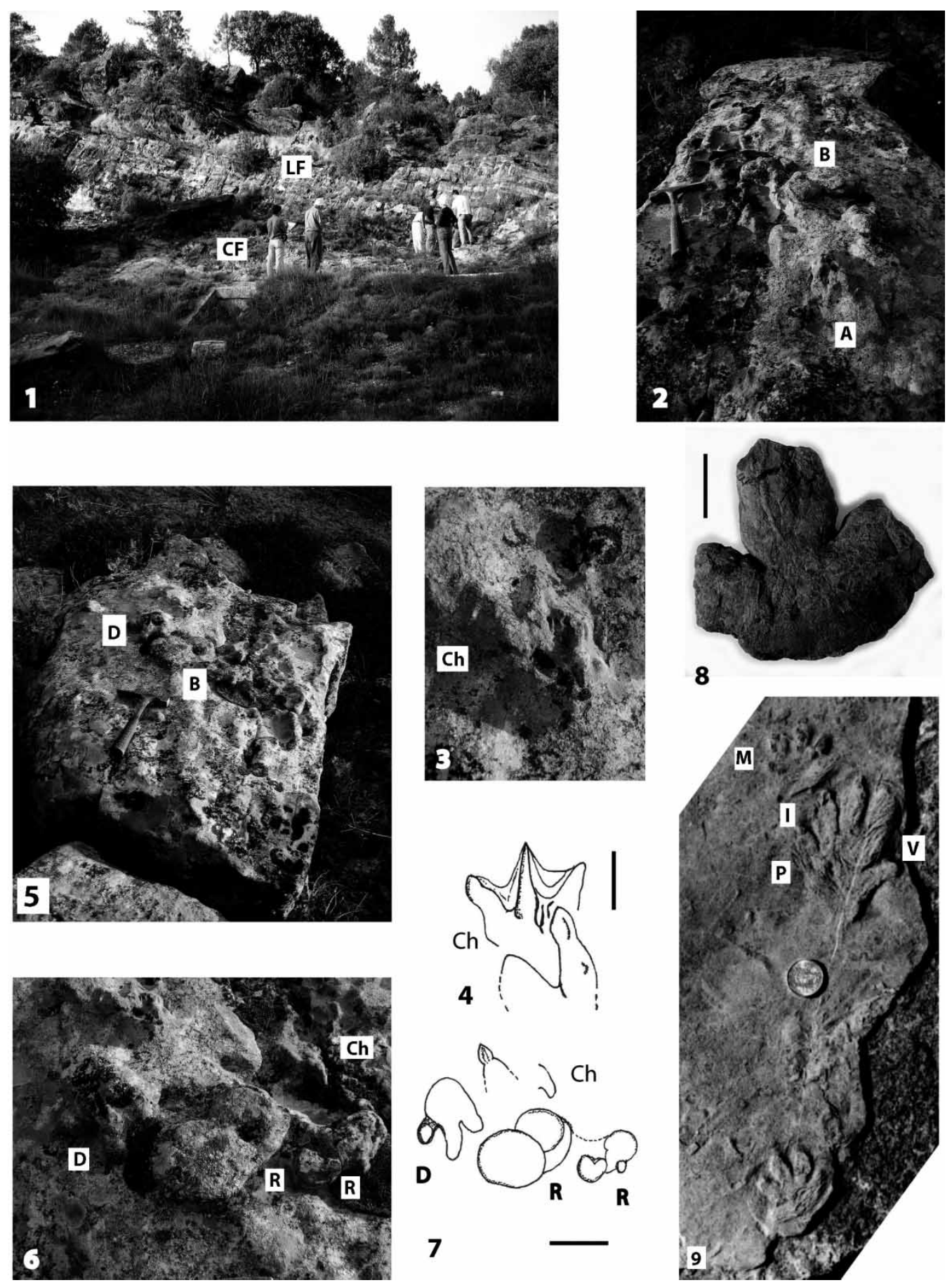

Plate 3. Landete Formation (base of Muschelkalk), Camarena and Boniches area, Chirotherium sp., cf. Brachychirotherium gallicum, 'Coelurosaurichnus' c f perriauxi, c f Paratrisauropus; 1: Outcrop near Cañete observed during the 2004 AGP trip, LF, Landete Formation upperlaying CF, Cañizar Formation; 2-3: A big white sandy dolomitic block bearing hyporelief footprints seen in the Landete Formation outcrops, 2: Frontal view, A and B details are enlarged in photographs 3 and 6; 3: Enlargement of detail A with chirotherioid (ch) traces; 4: Sketches of the detail B (from photograph 2); 5: Back view, details B and D are enlarged on photographs 6; 6: enlargement of detail B (from photograph 5) where D is a dinosauroid trace, $\mathrm{Ch}$ are chirotherioid traces, $\mathrm{R}$ are rounded coupled traces (cf Brachychirotherium couples); 7: Sketches from photograph 6; 8: Ornithoid footprints, base of the Landete Formation, Boniches area, cf Paratrisauropus latus, sample Boniches X; 9: Brachychirotherium gallicum pace trace, sample Camarena X, P: pes, M: manus, base of the Landete Formation, Camarena section, Cuenca Museum. Scale bar: $10 \mathrm{~cm}$, except for photograph 8: $5 \mathrm{~cm}$; coin diameter: $23 \mathrm{~mm}$. 
part of a pes (Plate 2,4). Its dimensions are: $\mathrm{L} £ \mathrm{~W}$ of the I-IV digital part $1 / 456 £ 56 \mathrm{~mm}$; successive I-III digit lengths $1 / 432,47,56 \mathrm{~mm}$. Because of the III-II length relative subequality, this footprint was first assigned to Isochirotherium closed to I. coureli; this last ichnospecies being selected because of the presence of balled claws in shape. However, the III/II length ratio $1 / 41.19$, exceeding the confidence interval at the $95 \%$ limit of I. coureli $(0.96-$ 1.09 ), it seems more appropriate to arrange only this Spanish trace in the Chirotherioid group like that suggested by the anonymous referee.

Boniches section, Landete Formation.

One metrical, white-pale sandy dolomite block (sample 26) turned upside down, located in the base of the Landete Formation (Plate 3, 1-LF, 2, 5) shows many hyporelief footprints. Most of them consist of superposed and uncomplete decimetric Chirotherium sp. (Plate 3, 2, 7-Ch). Other footprints of the same sample are heterometrical rounded coupled traces ( $\mathrm{R}$ in Plate 3, 2-7), possibly of Brachychirotherium sp. pes-manus. A similar ichno-preservation was also described in Gand (1978b:15), found in the Grès infe'rieurs Formation of the French Middle Triassic and related to B. pachydactylum. It is due to wide digits arranged in a very close pattern in the trackmaker autopods. Thus, when the animal moved on very wet substrates they may have produced this kind of sauropodoid footprints.

Comparison with previously described Spanish chirotherioid footprints (1897-1987)

Chirotherio1" $\mathrm{d}$ footprints of the Eslida Formation should be added to those from Spain already discovered as early as the nineteenth century. However, most of the footprints studied here are located in the same section and therefore they show a more detailed stratigraphic control.

Demathieu et al. (1978) described a Chirotherium sp. pes, almost complete, approximately $20 \mathrm{~cm}$ long, found in the Buntsandstein facies of Aragoncillo, NW Iberian Ranges, Rillo Formation (Ramos 1979). This ichnogenus was mentioned for the first time by Caldero'n (1897), lately related to Chirotherium gallicum by Leonardi (1959). In this latter revision, the author ascribed to Chirotherium diabloense and Chirotherium coltoni some traces pre-viously described with the ichnotaxa Chirosaurus ibericus by Navas (1906), all of them found in the Triassic of the Moncayo peak (Montaña de Arago'n Formation.), north of the Iberian Ranges. Although Haubold (1970) considered the latter chirotheriidae as indeterminated, C. ibericus was attributed to Synaptichnium diabloensis (Peabody 1948) by Demathieu et al. (1978), as well as C. coltoni was included in Isochirotherium coltoni (Haubold 1971).

The footprints found in the San Gaudioso de Moncayo locality, also in the Triassic of the Moncayo peak area by Go'mez de Llarena (1917), were related to C. barthii by
Leonardi (1959). The ichnogenus found in the Triassic of the Boniches section and described in this paper was also described at the base of the Buntsandstein facies in the Triassic series of the Catalan Coastal Ranges (Lapparent 1966; Calzada 1987).

Demathieu et al. (1978) described Synaptichnium sp., in the locality of Rillo de Gallo (Buntsandstein facies, Rillo Formation, Ramos 1979) and in the Riba de Santiuste locality (Muschelkalk facies, Cuevas de Ayllo'n Formation, Sopeña 1979), as well as Isochirotherium sp., found in the Buntsandstein facies, in the upper part of the Ermita del Buen Labrador section (Torete Formation, Ramos 1979; Figure 3). This latter ichnogenus trace, related to a manus print, is larger than broad.

The five different types (among others) of vertebrate ichnites presented by Calafat et al. (1986-1987) in the Buntsandstein facies of Mallorca, described as the A type trackway, were named 'Cheirotherium'. From the photos of these footprints, this assignation could be inexact because they show lacertoid manus-pes traces and the fourth digit is frequently the longest. Therefore, based on the position of the $\mathrm{V}$ digit compared to the I digit, the Hyloidichnus taxa could be better suited.

\section{Dinosauroid Group Nopsca, 1923; Dinosauromorpha Benton, 1985}

The ichnogenus 'Coelurosaurichnus' Huene 1941 had been synonymised with Grallator by Leonardi and Lockley 1995 and, thus referred to Theropoda. However, if Grallator was only made by Dinosauria, it is not possible to name the Middle Triassic dinosauroid footprints from this ichnogenus, as the trackmakers are not dinosauria (cf. supra), but their ancestors. For this reason, we have preferred to present the Spanish dinosauroid traces with their original ichnogenus, Coelurosaurichnus.

On the other hand, the holotypus Coelurosaurichnus toscanus, Huene 1941, was described from a deformed print, what returned it nomen vanum for Umberto Nicosia (Gand and Demathieu 2005), which does not approve the Leonardi and Lockley (1995) suggestion to do a synonymy between 'Coelurosaurichnus' and Grallator.

It appears clearly, based also on a statistical comparison, that the Middle Triassic French dinosauroid, such as 'Coelurosaurichnus' perriauxi Demathieu and Gand 1972, cannot be named Grallator sensu Lull (1953) and Olsen et al. (1998).

Therefore, in order to underline the nomenclatural problem concerning the 'Coelurosaurichnus' use, this ichnogenus will be written with commas in this paper.

'Coelurosaurichnus' sp., found in the Buntsandstein facies (Rillo Formation, Ramos 1979) and described in Demathieu et al. (1978), was the first description of this 
group in Spain. It seems that this ichnogenus could be present on the previously described block surface (sample 26) of the Landete Formation, in the Boniches section. In this sample, there is a digitigrade tridactyl II-IV footprint of $14 \mathrm{~cm}$ long, showing broad digits weakly clawed (Plate 3, 5-7). This unique trace is close to 'Coelurosaurichnus' perriauxi, frequently described in the Middle Triassic of the eastern border of the French Central Massif, (Demathieu and Gand 1972; Gand and Demathieu 2005; Gand et al. 2007).

Sample 27 was found by López-Gómez (1985) in the Boniches section, and here is described as a large tridactyl dinosauroid footprint of which the distal digits II-IV are lost (Plate 3, 8). The external II-IV angle of digits, which are very broad, is high (1208). This value characterises an ornithoid pes trace. Such footprints were described and classified by Demathieu and Weidmann (1982) from the Ladinian of Vieux Emosson (Valais, Switzerland). Although the Boniches print is clearly uncomplete, it seems that it should be close to Paratrisauropus latus Demathieu and Weidmann 1982.

Stratigraphical, paleontological and paleoenvironmental results

\section{Some datations from newly described footprints}

The new paleoichnological observations in the Boniches and Corbala'n sections expand the Chirotherium, Isochir-otherium,

Brachychirotherium, ' Coelurosaurichnus' and Rhynchosauroides ichnogenera presence to broader geographic domains of the Triassic of the Iberian Ranges. An incomplete trace, similar to Paratrisauripus, also suggests ornithoid footprints presence in the Muschelkalk facies (Landete This Formation) palichnological in the SE assemblage part of the confirms Ranges.the age of the overlying Landete Formation as Anisian, already known from ammonites and foraminifers (Ma'rquez et al. 1994; López-Gómez et al. 1998). Thus, the presence of Isochirotherium, close to I. coureli ichnospecies, distributed in the Grès inférieurs Formation of the northeast French Central Massif (Demathieu 1970; Demathieu and Gand 1986), and dated as upper Anisian-lower Ladinian (Demathieu et al. 1984). The Eslida Formation beds also bear I. cf coureli.

The Eslida Formation was previously dated as Anisian (Boulouard and Viallard 1982; Arche and Lo'pez-Go 'mez 1999, 2005). This formation is conformably overlain by the Marines and Landete Formations, containing rich palynomorph and foraminifer assemblages of middle-upper Anisian age (PelsonianIllirian) (Doubinger et al. 1990; López-Gómez and Arche 1993; Arche and López-Gómez 1999; López-Gómez et al. 2002, 2005). Therefore, it is reasonable to attribute an older age to the Eslida Formation and

locate ' $\mathrm{C}$ it in the oelurosaurichnusearly-middle' found Anisian.in the Landete and Rillo Formations, also is Anisian in age, because this ichnogenus was discovered in the upper Anisian-lower Ladinian interval in France (Demathieu et al. 1984; López et al. 2005) and in the upper Anisian of Italy (Avanzini 2002).

The cf. Paratrisauropus latus ornithoid trace of the Landete Formation (Plate 3, 8) has also an Anisian age, as the previously interpreted age of the level bearing this print.

Finally, we also confirm that the base of the Mallorca redbeds with Cheirotherium is not Triassic, but Late Permian in age, since the footprints described by Calafat et al. $(1986-1987)$ are Hyloidichnus. This conclusion is in agreement with previous studies that dated these beds as Thuringian, according to palynological analysis (Ramos and Doubinger

1989).

\section{Vertical range of Spanish footprints and comparisons}

Based on stratigraphic correlations, previous datations of the studied formations, and the five most representative localities bearing footprints in the Central and NW Iberian Ranges, as well as our comparisons with some references listed before of the Cantabrian Mountains, Catalan Coastal Ranges and Mallorca, we have detailed in Figure 6(A) the vertical distribution of Triassic ichnogenera currently indexed in Spain. For the Olenekian-Ladinian interval, Figure 6 shows that the Triassic palichnofauna of this country is related to others in areas such as Germany, France, England, USA and Africa, where footprints are also mentioned in the Late Triassic (Huene 1941; Peabody 1948; Baird 1957; Wills and Sarjeant 1970; Demathieu and Haubold 1972; Haubold 1984, 1986; Gand et al. 2007).

The palichnologic assemblages of the Middle Triassic in Spain and the above-mentioned areas show close relationships at the ichnogenera level, concerning the lacertoid, crocodiloid and dinosauroid groups. However, for this time interval in Spain, the smaller content of footprints makes difficult the ichnospecific determination. In this aspect, the Dinosauromorpha Rotodactylus Peabody 1948, mentioned from the Lower to the Upper Triassic, and Sphingopus (Demathieu 1966) probably related to Ornithosuchidea, are not found in Spain. This absence could be due to gaps in the sedimentary record, among other reasons.

However, comparative studies of the Middle Triassic ichnospecific contents show that the Spanish ichnospecies Rhynchosauroides virgiliae, Brachychirotherium gallicum and Isochirotherium cf. coureli are commonin France. In a similar way, the Spanish samples of Isochirotherium coltoni and Chirotherium diabloense are also abundant in the Lower Triassic of USA (Lull 1953). The omnipresence of Chirotherium barthii, indexed in the Triassic world from the Olenekian to the Ladinian, is, however, rather uncommon in Spain. 


\section{Paleontological interpretations}

Since the mid-1990s, there is good agreement concerning the general paleontological interpretations of trackmakers of different Triassic ichnospecies, as shown by different authors (Peabody 1948; Baird 1957; Demathieu 1970; Haubold 1970, 1971; Demathieu and Haubold 1974; Courel et al. 1982; Avanzini and Renesto 2002; Benton 2005; Gand et al. 2007). Therefore, we can assert that Rhynchosauroides of the Eslida Formation is related to Lepidosauria (Prolacertiforms), 1-2 $\mathrm{m}$ long, that were living together with larger crurotarsian carnivorous as Chirotherium, Isochirotherium and Brachychirotherium. From previously described Spanish footprints in Demathieu et al. (1978), concerning several formations of the Iberian Ranges, we know that the Middle Triassic palichnofauna of the Iberian Plate was differentiated in Synaptichnium sp., due to Archosauriformes (? Euparkeria), and 'Coelurosaurichnus' sp., footprints related to Dinosauriformes.

Cf Paratrisauropus latus from the Boniches locality means probably pre-ornithischian animals. These animals were suggested from 'Coelurosaurichnus' sabinensis footprints, and also from ornithoid traces found in the Middle Triassic of France (Gand et al. 1976a, 1976b).

Finally, Procolophonichnium sp., found in Triassic rocks of the Cantabrian Cordillera of undetermined age (Demathieu and Saiz de Omeñaca 1978, 1990), is classically ascribed to little Parareptiles (formerly named Cotylosauria).

\section{Paleoenvironmental implications}

The described footprints are commonly related to several sedimentary structures, such as current ripples, mudcracks, parting lineation, rain-drops marks and others of early diagenetic origin, as halite hoppers (Arche and López-Gómez 1999, 2005). This information, added to other paleontological and sedimentological data concerning regional studies in the Middle Triassic in the Iberian Ranges (Pérez-Arlucea and Sopeña 1985; Ramos et al. 1986; Gómez-Gras 1993; Sánchez-Moya et al. 2004; Bourquin et al. 2007), have allowed us to make some considerations about the paleoenvironments of the different studied formations bearing footprints.

It could be considered that the landscape during the Middle Triassic in the Iberian microplate was formed by very extensive, lowlands around the highly weathered Hercynian reliefs. This landscape probably extended far towards the south of Armorique and Devon (Dercourt et al. 1993). However, during the early Anisian times, the SE Iberian basin or present-day Iberian Ranges, was an active tectonically controlled intracratonic basin as result of the connection of two main rift systems in the E of Iberia, one of them coming from the Central Europe plate, with a general N.NE-S.SW trend, and the other represented by the NW-SE Iberian basin rift system (Arche and LópezGómez 1996). This connection resulted in an active and immense fluvial system plain with wide flood plains and playa environments, represented by the Eslida Fm., in which Reptiles, such as Crurotarsi, Lepidosauria, Archosauria (whose Dinosauriformes) and Parareptiles, were living. This tectonic control could be somehow responsible for the environmental conditions changes and therefore, for the presence and diversity of the reptiles, as was recently proposed by Diedrich (2009) for the Middle Triassic of Central Europe.

Some of the footprints were probably made during emersion periods of fluvial plains and were preserved in the desiccated zones of overbanks. Presence of mudcracks, halite hoppers and rain-drops underline a climate with dry and wet period alternations. This interpretation is confirmed also by the plant assemblage nature which was observed in the different biotas. The macroflora remains are frequent in the Eslida Formation (Arche and LópezGómez 1999) where they appear associated with footprints, often on the same levels (Plate 2, 5). In Catalonia, NE Spain, in the section of Caldes, equivalent in time to the upper part of the Cañizar Formation and the Eslida Formation, Calzada (1987) mentioned Equisetites cf. mougeotti, Equisetophytina growing in wetlands, and Coniferophytina such as Aetophyllum sp., an herbaceous plant, as well as abundant Voltzia trees. These two latter genera of the Triassic euramerican flora were well adapted to the dryness characterising an overall hot climate (Lemoigne 1988).

From the middle Anisian times onwards, the Buntsandstein continental red beds were progressively covered by the onlapping deposits of the Muschelkalk during the westward transgression of the Tethys Sea (Sopeña et al. 1988; López-Gómez et al. 1998), here represented by the Landete Fm. Eustatic changes in sea level were also important and produced changes in the tidal flat subenvironments represented by this latter unit. This control can be observed in Figure 6(A) that shows the progressive displacement of these tidal facies belt from east to west and, at the same time, from base to top of the series, a disposition that represents the time interval that took to the coast to reach the interior of the microplate. This displacement was probably followed by the reptiles that migrated almost parallel to this belt towards the interior of the Iberian plate.

Inferred from the vertical distribution of the footprints, Figure 6(B) shows how the fauna modifications during the Middle Triassic times did not change at the large clades level. They were always Crurotarsi and Lepidosauria, except for the Dinosauriformes revealed by 'Coelurosaurichnus' traces. They do not seem to appear before the middle Anisian base, a fact that is also known in France and Italy (Avanzini 2002; Gand and Demathieu 2005). It could be related to a protracted recovery of life after the Permian-Triassic crisis in this area. 


\section{Conclusions}

The Spanish Triassic rocks have a great palichnologic potential due to the huge and well-preserved outcrops. The new discoveries in the Can izar, Eslida and Landete Formation (27 samples) of the SE Iberian Ranges in four different sections, support this point of view. They complete the Middle Triassic palichnofauna already described in the Iberian Ranges and Cantabrian Mountains. From the samples studied here, it is possible to identify the same ichnogenera as in North America and Europe, with some ichnospecies being common with other ones previously found in the Middle Triassic of France and USA. All these footprints testify the presence of varied Crurotarsi and Lepidosauria, which present ancestrals in the Early Triassic. From the late Anisian, the fauna is gradually growing richer in Dinosauriformes, whose existence is proven in France, Italy and Spain by 'Coelurosaurichnus' footprints. These biped reptiles are the ancestors of Dinosaurs who will later develop at the beginning of Carnian.

The continental Buntsandstein red beds bearing footprints in the Middle Triassic of the Iberian Ranges were related to vast fluvial systems with important flood plains and playa environments, in a paleogeographic domain which includes the south of Armorique and Devon areas. At the end of the Anisian, the environment evolved into a shallow carbonate platform with large lagoon or restringed areas, but still under the same previous hot climate characterised by alternations of dry and rainy seasons. The continental environments were colonised by wetlands plants such as Equisetites, but also by Coniferal species adapted to the dryness, such as Voltria. Inferred from the vertical distribution of the footprints, it is possible to assume that the fauna modifications during the Middle Triassic times were small at a high clade level. The footprints were always related to Crurotarsi and Lepidosauria, except for the Dinosaur-iformes revealed by 'Coelurosaurichnus' t $\mathrm{r}$ a c e s .

In the Iberian microplate, the general footprints content for the Middle Triassic is smaller than that in other neighbouring countries to the north. On the other hand, in the Triassic, there are not footprints preserved before the Anisian, as it also happen in other perythetyan countries. In this area and other western Pangea areas, the reason for this absence of footprints could be due to a protracted recovery of life after the endPermian extinction.

\section{Acknowledgements}

This paper is a contribution to the project CGL2008-00093 of the Spanish Ministry and to projects UCM-BSCH-GR58/08: Analisis de Cuencas (910429) and Paleoclimas (910198) of the Complutense University-Comunidad Auto'noma de Madrid. We thank Nombre Belvedere and an anonymous referee for improving this manuscript with their comments. We also thank Direccio'n General de Patrimonio Cultural del Gobierno de Arag' on (number 219/2008) for the permission for doing the research in the Teruel province.

\section{References}

Abel O. 1926. Der erste Fund einer Tetrapodenfa“hrte in den unteren alpinen Trias. Pal Zeitsch. 7:22-24.

Arche A, López-Gómez J. 1996. Origin of the Permian-Triassic Iberian Basin, central-eastern Spain. Tectonophysics. 266:443-464. Arche A, Lo pez-Go'mez J. 1999. Tectonic and geomorphic controls on the fluvial styles of the Eslida Formation, Middle Triassic, Eastern Spain. Tectonophysics. 315:187-207.

Arche A, López-Gómez J. 2005. Sudden changes in fluvial style across the Permian-Triassic boundary in the eastern Iberian Ranges, Spain: analysis of possible causes. Palaeogeogr Palaeoclimatol Palaeoecol. 229:104-126.

Avanzini M. 2002. Dinosauromorph tracks from the Middle Triassic (Anisian) of the Southern Alps (Valle di Non-Italy). Boll Soc Paleontol Ital. 41(1):37-40.

Avanzini M, Renesto S. 2002. A review of Rhynchosauroides tirolicus Abel, 1926 ichnospecies (Middle Triassic: Anisian-Ladinian) and some inferences on Rhynchosauroides trackmaker. Riv Ital Paleontol Stratigr. 108(1):51-66.

Avanzini M, Ceoloni P, Conti MA, Leonardi G, Manni R, Mariotti N, Mietto P, Muraro C, Nicosia U, Sacchi E, et al. 2001. Permian and Triassic Tetrapod ichnofaunal units of northern Italy: their potential contribution to continental biochronology. "Natura Bresciana", Ann Mus Civ Sc Nat Brescia. 25:89-107.

Baird D. 1957. Triassic Reptile footprint faunules from Milford, New Jersey. Bull Mus Comparat Zool. 117(5):449-550.

Benton MJ. 1985. Classification and phylogeny of the diapsid reptiles. Zool J Linn Soc. 84:97-164

Benton MJ. 2005. Vertebrate palaeontology. 3rd ed. Oxford: Blackwell Publishing. $453 \mathrm{p}$.

Beurlen K. 1950. Neue Fa"hrtenfunde aus der Fränkischen Trias. Neues Jahrbuch Monatshefte. p. 308-320.

Boulouard Ch, Viallard P. 1982. Re'duction ou lacune du Trias infe' rieur sur la bourdure meditérraneenne de la Chaîne Ibérique: arguments palynologiques. C R Acad Sci Paris. 295:803-808.

Bourquin S, Durand M, D1'ez JB, Broutin J, Fluteau F. 2007. The PermianTriassic boundary and Early Triassic sedimentation in Western European basins: an overview. J Iber Geol. 33(2):221-236.

Calafat F, Fornós JJ, Marzo M, Ramos-Guerrero E, Rodrí guez-Perea A. 1986-1987. Icnología de vertebrados de la facies Buntsandstein de Mallorca. Acta Geol Hisp. 21-22:515-520.

Caldero'n S. 1897. Una huella de Chirotherium de Molina de Arago'n. Act Soc Esp Hist Nat. 26:27-29.

Calzada S. 1987. Niveles fosilíferos de la facies Buntsandstein (Trias) en el sector de los Catalánides. Cuad Geol Ibe'r. 11:256-271.

Courel L, Demathieu G, Gand G. 1982. Contribution apporte'e par l'ichnologie a' quelques disciplines de la Ge'ologie. Me'moire de l'Institut des Sciences de la Terre, Universite' de Dijon. 7:313-326. De

Vicente G, Muñoz-Martín A, Van Wees JD, Casas-Sa' inz A, Sopeñ a A, Sánchez-Moya Y, Arche A, Lo'pez-Go'mez J, Olaiz A, Ferna'ndezLozano J. 2009. Oblique strain portioning and transpression on an inverted rift: the Castillian Branch of the Iberian Chain. Tectonophysics. 470(3-4):224-242.

Demathieu G. 1966. Rhynchosauroides petri et Sphingopus ferox. Nouvelles empreintes de Reptiles des gre's triasiques de la bordure Nord-Est du Massif Central. C R Acad Sc Paris. 263:483-486. Demathieu G. 1970. Les empreintes de pas de vertébrés du Trias de la bordure N-E du Massif Central. Cahiers de Pale'ontologie CNRS Paris. p. $1-211$.

Demathieu GR, Gand G. 1972. 'Coelurosaurichnus' perriauxi, empreinte dinosauror" de nouvelle du Plateau d'Anthully. Bull Soc Hist Nat Autun. 62:2-18.

Demathieu G, Gand G. 1986. Palichnologie: interpre'tation pale'oe'cologique de traces d'origine me' chanique et biologique observées dans la carrière triasique de Saint-Ve'rand. (Saonne et Loire, France). Bull Soc Hist Nat Autun. 119:7-30.

Demathieu G, Haubold H. 1972. Stratigraphische Aussagen der Tetrapodenfährten aus der terrestrischen Trias Europas. Sonderdruck aus Geologie Berlin. 7:802-836.

Demathieu G, Haubold H. 1974. Evolution und Lebensgemeinschaft terrestrischer Tetrapodenden nach ihren Fährten in der Trias. Freiberge Forschungshefte. 298:51-71. 
Demathieu G, Oosterink HW. 1983. Die Reptilienfa“hrten aus der Mitteltrias der Niederlande. Nederlandse Geologische Vereniging, Staringia. 7:52 p.

Demathieu GR, Saiz de Omeñaca J. 1976. La faune ichnologique du Trias de Puentenansa dans son environnement pale'oge'ographique (Santander, Espagne). Bull Soc Ge'ol France. 7(28):1251-1256.

Demathieu GR, Saiz de Omen aca J. 1978. Keckia multiplum, n. sp. de la fauna ichnolo' gica del Tria'sico. Breviora Geol Astu'rica. 22:8-9.

Demathieu GR, Saiz de Omeñaca J. 1979. Caracterı'sticas y significado del Rhynchosauroides extraneus, n. sp., y otras nuevas huellas del Tria'sico de Cantabria. Bol R Soc Esp Hist Nat (Geol). 77:91-99.

Demathieu GR, Saiz de Omeñaca J. 1990. Primeros resultados del estudio de un nuevo yacimiento de icnofauna tria'sica, en Peña Sagra (Cantabria, España). Estud Geol. 46:147-150.

Demathieu G, Weidmann M. 1982. Les Empreintes de pas de Reptiles dans le Trias du Vieux Emosson, Finhaut, Valais, Suisse. Eclogae Geol Helvet. 75/3:721-757.

Demathieu G, Ramos A, Sopeña A. 1978. La fauna icnologica del Tria'sico del extremo noroccidental de la Cordillera Ibe'rica (Prov. de Guadalajara). Estudios Geol. 34:175-186.

Demathieu G, Courel L, Durand M. 1984. Pale'oichnologie des verte'bre's. In: Debrand-Passard S, Courbouleix S, Lienhardt MJ, editors. Synthe'se Ge'ologique du Sud-Est de la France: Stratigraphie et Pale'oge'ographie. Me'moire Bureau Recherches Ge'ologiques et Minie 'res, Orle' ans-la-Source. 126(1):63-64.

Dercourt J, Ricou LE, Vrielynck B, editors. 1993. Tethys palaeoenvironment maps. Paris: Gauthier-Villars. 307 p

Diedrich C. 2000. Neue Wirbeltierfarthen aus dem Unteren Muschelkalk (Mitteltrias) des Osnabrücker Berglandes und Teutoburger Waldes (NW-Germany) und ihre stratigraphische und pala"eogeographische Bedeutung im Germanische Beken. N Jb Geol Paläont Abh. 217(3):369-395.

Diedrich C. 2009. Palaeogeographic evolution of the marine Middle Triassic marine Germanic Basin changements - with emphasis on the carbonate tidal flat and shallow marine habitats of reptiles in Central Pangaea. Global Planet Change. 65:27-55.

Doubinger J, L'opez-Go'mez J, Arche A. 1990. Pollen and spores from the Permian and Triassic sediments of the Iberian Ranges, Cueva de Hierro (Cuenca) to Chelva - Manzanera (Valencia-Teruel) region, Spain. Rev Palaeobot Palynol. 66:25-45.

Faber FJ. 1958. Fossiele voetstappen in der Muschelkalk van Winterswijk. Geol en Mijnb NS. 20:317-320.

Gaete R, Galobar A, Palomar J, Marzo M. 1996. Primeros resultados sistema'ticos y bioestratigra' ficos del yacimiento de tetra' podos fo'siles de la facies Buntsandstein de La Mora (Pla de la Calma, Barcelona). Cuad Geol Ibe'r. 20:331-345.

Gand G. 1978a. Sur le mate'riel ichnologique re' colte' dans le Muschelkalk de Culles-les-Roches (Saône et Loire). Bull Soc Hist Nat, Le Creusot. 35(2):21-44.

Gand G. 1978b. Interpre'tations pale' ontologique et pale'oe' cologique d'un sixie 'me assemblage a' traces de Reptiles des carrie'res triasiques de StSernin-du-Bois (Autunois, France). Conclusions ge'ne'rales a' l'e 'tude du gisement fossilife`re. Bull Soc Hist Nat Autun. 87:9-29.

Gand G, Demathieu G. 2005. Les pistes dinosaurö"des du Trias moyen franc, ais: interpre'tation et re'e'valuation de la nomenclature. Geobios. 38:725-749.

Gand G, Demathieu G, Montenat C. 2007. Les traces de pas d'Amphibiens, de Dinosaures et autres Reptiles du Me'sozor que franc,ais: Inventaire et interpre'tations. Palaeovertebrata. 35:141.

Gand G, Pellier F, Pellier JF. 1976a. Coelorosaurichnus sabinensis: Trace triassique nouvelle de la bordure N-E du Massif-Central. Bull Soc Hist Nat Autun. 79:19-22.

Gand G, Pellier F, Pellier JF. 1976b. Sur quelques traces ornithor"des re'colte'es dans le Trias moyen de Bourgogne. Bull Soc Hist Nat, Le Creusot. 34(1):24-33.

Go'mez de Llarena J. 1917. La estratigrafía del Moncayo. Bol R Soc Esp Hist Nat. 17:568-572.

Go'mez-Gras D. 1993. El Permotrías de las Baleares y de la vertiente mediterr' an e a d e la C o r d i l l e r a I b 'e rica y del Maestrat: facies y Petrologi'a Sedimentaria (Parte II). Bol Inst Geol Min España. 104:467-515.

Goy A, Go'mez J, Ye'benes A. 1976. El Jura'sico de la Rama Castellana de la Cordillera Ibe'rica (mitad norte). I Unidades litoestratigra'ficas. Estud Geol. 32:391-423.
Haubold H. 1970. Versuch ciner Revision der Amphibien Fa“hrten des Karbon und Perm. Freiberger Forschungschefte, Leipzig C. 260:83-109.

Haubold H. 1971. Ichnia Amphibiorum et Reptiliorum fossilium. In: Handbuch der palaoherpetologie. Vol. 18. Stuttgart: Encyclopedia of Paleoherpetology. 123 p.

Haubold H. 1984. Die Fossilen Saurierfahrten. Wittenberg Lutherstadt, Neue Brehm Bücherei. 230 p.

Haubold H. 1986. Archeosaur footprints at the terrestrial Triassic-Jurassic transition. In: Padian K, editor. The beginning of the age of the dinosaurs. New York (NY): Cambridge University Press. p. 189-209.

Huene F (von). 1941. Die Tetrapoden Fa“hrten im toskanischen Verrucano und ihre Bedeutung. Neues Jahrbuch für Mineralogie Geologie und Paleontologie. 86:1-34.

Kaup JJ. 1835. Thier-Fa"hrten von Hidelburghausen: Chirotherium oder Chirosaurus. Neues Jahrbuch fur Mineralogie Geologie und Palao"ntologie. p. 327-328.

Lapparent A (de). 1966. Nouveaux gisements de Reptiles Mesozoiques en Espagne. Not Comuns Inst Geol Minero de España. 84:103-110.

Lemoigne Y. 1988. La flore au cours des temps ge'ologiques. Geobios. 2:296 p.

Leonardi P. 1959. Orme chiroteriane triassiche spagnole. Estud Geol. 15:235-245.

Leonardi G, Lockley MG. 1995. A proposal to abandon the ichnogenus Coelurosaurichnus Huene 1941-a junior synonym of Grallator Hitchcock 1858. J Vertebr Paleontol. 15:40A.

Lopez M, Gand G, Garric J, Galtier J. 2005. Playa environments in the Lode ve Permian Basin and the Triassic cover (Languedoc-France) Excursion, 10-12 May 2005. Association des Se'dimentologistes Franc, ais. 54 p.

López-Gómez J. 1985. Sedimentología y estratigrafía de los materiales pe'rmicos y tria'sicos del sector SE de la Rama Castellana de la Cordillera Ibe 'rica entre Cueva de Hierro y Chelva (provincias de Cuenca y Valencia) Seminarios de Estratigrafi' a, Serie Monografi' as. 11:1-344.

López-GómezJ, Arche A. 1993. Sequence stratigraphy analysis and paleogeographic interpretation of the Buntsandstein and Muschelk-alk facies (Permo-Triassic) in the SE Iberian Ranges, eastern Spain. Palaeogeogr Palaeoclimatol Palaeoecol. 103:347-361.

López-Gómez J, Arche A, Calvet F, Goy A. 1998. Epicontinental marine carbonate sediments of the Middle and Upper Triassic in the westernmost part of the Tethys Sea, Iberian Peninsula. In: Bachmann GH, Lerche I, editors. Epicontinental Triassic. Zentral für Geol und Pala“ont (1) 9-10:1033-1084.

López-Gómez J, Arche A, Pe'rez-Lo'pez A. 2002. Permian and Triassic. In: Gibbons W, Moreno T, editors. The geology of Spain. London: Geological Society of London. p. 185-212.

López-Gómez J, Arche A, Marzo M, Durand M. 2005. Stratigraphical and palaeogeographical significance of the continental sedimentary transition across the Permian-Triassic boundary in Spain. Palaeo-geogr Palaeoclimatol Palaeoecol. 229:3-23.

Lull R-S. 1953. Triassic life of the Connecticut Valley. State Geological and Natural History Survey, Hartford. 24:331 p.

Maidwell FT. 1911. Note on footprints from the Keuper of Runcorn Hill. Liverpool Geol Soc Proc. 11:140-152.

Ma'rquez L, Lo'pez-Go'mez J, Trifonova Ek. 1994. Datacio'n (foraminı' feros) y ambientes sedimentarios de la Formacio'n Dolomi'as de Landete, Anisiense, Facies Muschelkalk, provincia de Cuenca. Bol Real Soc Esp Hist Nat. 89:99-107.

Navas L. 1906. El Chirosaurus ibericus sp. nov. Bol Soc Arago'n Cienc Nat. 5:208-213.

Nopsca F. 1923. Die Familien der Reptilien. Fortschritte der Geologie und Paläontologie, Berlin. 2: 210 p.

Olsen PE, Smith JH, Mc Donald NG. 1998. Type material of the type species of the classic theropod footprint genera Eubrontes, Anchisauripus and Grallator, Early Jurassic, Hartford and Deerfield basins, Connecticut and Massachusetts, USA. J Vert Pal. 18(3):586601.

Peabody FE. 1948. Reptile and Amphibian trackways from the Lower Triassic Moenkopi Formation of Arizona and Utah. Berkeley: University of California Press. 420 p.

Pe'rez-Arlucea M, Sopeña A. 1985. Estratigrafía del Pe'rmico y Tria'sico en el sector central de la Rama Castellana de la Cordillera Ibe'rica (provincias de Guadalajara y Teruel). Estud Geol. 41:207-222. 
Ramos A. 1979. Estratigrafía y paleogeografía del Pérmico y Triásico al oeste de Molina de Aragón (Provincia de Guadalajara). Seminarios de Estratigrafía Serie Monografías. 6:1-313.

Ramos A, Doubinger J. 1989. De'couverte d'une microflore Thuringian dans le Buntsandstein de la Cordillere Iberique (Espagne). C R Acad Sci, Paris. 289:525-528.

Ramos A, Sopeña A, P 'e rez-Arlucea M. 1986. Evolution of Buntsandstein fluvial sedimentationin the northwest Iberian ranges (Central Spain) J Sed Petrol. 56:862-875.

Sánchez-Moya Y, Arribas J, Garc1'a-Gil S, Go'mez-Gras D, Marzo M, Pérez-Arlucea M, Sopeña A. 2004. Desarrollo del rifting. La generalización de la subsidencia y los depo'sitos fluviales asociados. In: Vera JA, editor. Geolog1'a de España. Sociedad Geolo'gica de España IGME. p. 485-487.

Sereno PC, Arcucci BA. 1990. The monophyly of crurotarsal archosaurs and the origin of bird and crocodile ankle joints. Neues Jahrbuch fûr Geologie und Pala"ontologie, Abhandlung. 180:21-52.
Silvestri SM, Olsen PE. 1988. Uniquely preserved trackway of the reptile ichnotaxon Rhynchosauroides hyperbates Baird from the Late Triassic of Arcola, Pennsylvania, associated forms, and significance to Carnian-Norian extinction. Geol Soc Am. 20:1-70.

Soergel W. 1925. Die Fa"frten der Chirotheria. Eine pala"obiologische Studie. In: G. Fischer editor. Jena. 92 p.

Sopeña A. 1979. Estratigrafía del Pérmico y Triásico del NO de

la provincia de Guadalajara. Seminarios de Estratigrafía, Serie Monografi'as. 5:1-329.

Sopen a A, L 'o pez-Go'mez J, Arche A, Pe'rez-Arlucea M, Ramos A Virgdi, Hernando S. 1988. Permian and Triassic rift basins of the Iberian Peninsula. In: Manspeizer W, editor. Triassic-jurassic rifting. Vol. 22 Amsterdam: Elsevier. Developments in Geotectonics. p. 757-786.

Willruth K. 1917. Die Fa"hrten von Chirotherium. Zeitschrift für Naturwissenschaften. 86:395-433.

Wills LJ, Sarjeant AS. 1970. Fossil vertebrate and invertebrate trackfrom boreholes through the Bunter series. The Merc Geol. 3:389-414 